\title{
Institutional Arrangements Governing Wetland Utilization and Conservation in Communal Areas of Zimbabwe
}

\author{
Thomas Marambanyika a*, Heinz Beckedahl b \\ a Department of Geography and Environmental Studies, Midlands State University, Gweru, P. Bag 9055, Zimbabwe. \\ Phone: +263773568278 . Fax +26354223795 . \\ b Department of Geography, Environment Science and Planning, University of Swaziland, Kwaluseni Campus, Private Bag 4, \\ Kwaluseni, Swaziland, M201 \\ ${ }^{*}$ Corresponding author's email address: tmarambanyikat@yahoo.co.uk
}

\section{A R T I C L E I N F O}

Received: 15-09-2016

Accepted: 22-10-2016

Available online: 01-01-2017

\section{Keywords:}

Local Communities;

Wetland Governance;

Wetland Management;

Stakeholder Participation.

JEL Classification:

Q01, Q15, Q24, Q25, Q28

\begin{abstract}
A B S T R A C T
Wetland degradation and loss has persisted in developing countries due to existence of poor institutional frameworks supporting wetland governance. Therefore, wetland ecosystem services that support the livelihoods of most subsistence populations in rural areas are concomitantly lost. This paper explores the nature and consequences of institutional arrangements governing wetland access, utilization and conservation in six communal wetlands in Zimbabwe. Data were collected through a household survey targeting one hundred and twenty-three household heads, sixty teenagers and key informant interviews. The results of the study indicate a complex, multi-institutional involvement and the roles and relationship of participating institutions often compromise wetland resources conservation as a result of conflicts, confusion and tensions exacerbated by divergent motives. There is no homogeny in the number of institutions determining utilization at each wetland nor their degree of influence on management decisions; a situation reflecting inconsistency in existing institutional structure at communal level. Given the proximity of traditional leaders and wetland committees to the people and wetlands and the poor participation of government agencies, an institutional structure which places local institutions at the core of the governance system should be formulated. This should be complemented by a clear framework which promotes co-ordination of institutional roles and clarification of their relationships in order to minimize discord in execution of their duties; a situation that currently contributes to degradation of wetland ecosystems. The necessary policy and legal framework to support such institutional framework should be put in place and resources for its operations made available.
\end{abstract}

This is an open access article under the terms of the Creative Commons Attribution License 4.0, which allows use, distribution and reproduction in any medium, provided the original work is properly cited.

DOI: http://dx.doi.org/10.18533/rss.v2i1.71

ISSN: 2378-8569(Print), ISSN: 2378-8550(Online)

\subsection{Introduction}

Healthy wetlands deliver a wide range of important goods and services to society (Turner et al., 2000; Macfarlane et al., 2007). Wetlands have therefore been sustaining communal livelihoods for centuries in developing countries mainly through cultivation and livestock grazing. However, Zimbabwe has been experiencing a progressive loss of wetlands over the past decades resulting in significant loss of benefits to society (Matiza, 1994; Mutepfa et al., 2010). According to Katerere (1994), Zimbabwe has lost more than half of its wetlands since the time Europeans settled in the country. Wetland mismanagement has been identified as a 
key factor influencing wetland degradation and loss in the country (Mbereko, 2008; Mutepfa et al., 2010). Effective management of wetland ecosystem, instead of preservation, is therefore essential if wetland attributes are to be retained within an ever-changing socio-economic landscape (Boast, 1990; Kotze, 2010; Macfarlane et al., 2007).

Given the complex physical, biological and socio-economic processes determining their existence, the management and conservation of wetlands is not easy (Turner et al., 2000). Therefore, research should target the factors at interplay at every wetland site, if wetlands are to be effectively managed. Most studies revealed that successful use and management of wetland systems can be achieved if planners and policy makers understand the relationship between wetlands, people and existing human institutions (Shine and de Klemm, 1999; Maconachie et al., 2008; Dixon et al., 2013). This occurs as utilization of wetlands is often influenced by dynamic institutional arrangements peculiar to each place (Dugan, 1992; Mitsch and Gosselink, 1993). The study of human institutions in wetland management is therefore of significance in maintaining and restoring wetland integrity as appropriate measures can be put in place to improve the existing institutional structures as expected under Ramsar guidelines for wise use of wetlands. Previous research findings have highlighted that institutional conflicts arising from divergent priorities and objectives as well as institutional laxity are some instrumental factors behind wetland loss (Chidzonga, 1994; Frenken and Mharapara, 2002; McCartney et al., 2005).

Chuma et al. (2008:55) defined institutions as 'social arrangements that shape and regulate human behaviour, have some degree of permanency and purpose, and transcend individual human lives and intentions'. It is through these institutions that rules governing wetland resource use, control and management are shaped (Murombedzi, 1994; Dixon and Wood, 2007). Institutions are made up of the institutional environment and institutional arrangements (Chuma et al., 2008). Institutional arrangements, which are the focus of this research, refer to the structure that humans impose on their dealings with each other whereas institutional environment refers to the rules governing institutions. Spatio-temporal variations were observed in actual institutional arrangements worldwide (Acres et al. 1985; Mharapara et al. 1998; Dixon and Wood 2007; Maconachie et al. 2008). This has resulted in institutional arrangements being interpreted differently by different people depending on what they want to achieve so that ultimately the outcomes of these governance structures vary. The differences in institutional arrangements underline the importance of analyzing institutional arrangements spatio-temporal performance (Maconachie et al. 2008). The current body of literature has concluded that generally institutional arrangements in most developing countries are weak and have been unable to abate wetland ecosystems loss (Mahonge, 2010; Dixon et al., 2013; Jamu et al., 2013; Were et al., 2013). This is interpreted as a clear indicator that research to improve institutional structures in developing countries, including Zimbabwe where there is dearth of literature to support this proposition, is required. Some recent research on wetlands governance in Zimbabwe has been focusing on legislative and policy issues (Marambanyika and Beckedahl, 2016) without precisely zooming into the effect of existing institutional arrangements on wetland protection. This explains why Msipa (2009) argued that wetland monitoring for management in Zimbabwe needs to take note of institutional changes that can deal with changing conditions. Since the introduction of the Environmental Management Act in 2003, no research has been focused on understanding whether this new legal paradigm shift has assisted to shape institutional structure which can improve wetland protection.

During the pre-colonial period, traditional institutions in southern Africa have been instrumental in management and conservation of natural resources in their socio-political and economic interest (Mogale et al., 2010). Most of the indigenous institutions were relatively effective, resulting in sustainable utilization of natural resources (Dore 2001). While this may be true, it is important to note that pre-colonial population density and land use which would directly and indirectly affect wetlands were significantly different to the present. Further, the role of external factors such as new markets which create pressure on wetland resources should not be ignored (de Prada et al. 2014). The capacity of indigenous institutions in natural resource management was, however, weakened by interference and institutional disruptions initiated by colonial governments. In most developing countries, including Zimbabwe, it was found that a colonial legacy (which was later inherited by post-colonial governments) set up a resource governance system which largely ignored indigenous knowledge and common practice. Nevertheless, traditional institutions have remained largely intact, although they are weak (Dore, 2001; Pollard, 2005; Mogale et al., 2010). Meanwhile, the degree of co-operation between government resource management agencies and local communities as well as traditional decision making authorities still vary across southern Africa (Mogale et al., 2010).

The level of success of institutions in natural resource governance is determined by dynamic factors. The ability of a given institution to fulfil its mandate depends on power relationships, the source of mandate and political rightness or acceptability (Dugan, 1992; Gumbo, 2006; Maconachie et al., 2008; Silima, 2007). Politicians' 
understanding of the importance of wetlands and the role played by institutions is therefore crucial for their conservation (Katerere, 1994). Thus Maconachie et al. (2008) emphasize the importance of exploring the role that power relationships assume at all scales in formulating land-use decisions and determining access to resources within wetland environments. Lack of human and financial capacity, jealousies and absence of crosssectoral communication channels also weakens institutions' capacity (Katerere, 1994; Matiza, 1994; Mharapara et al., 1998; Gumbo, 2006; Mutyavaviri, 2006). Imposed institutional arrangements by governments are further blamed for participation of external institutions which often ignore views of the local people (Keeley and Scoones, 2000; Frenken and Mharapara, 2002; Silima 2007; Mbereko, 2008). Since it is a requirement under Zimbabwe's National Environmental Policy of 2009 to establish and support effective institutional framework for sustainable natural resources management, the present research ascertained the extent to which this can be accomplished in regard to wetland conservation.

In Zimbabwe wetlands, just like any other natural resource, are communally used and managed. The communal system of resource ownership entails that communities are in 'de facto' ownership of the wetlands on behalf of 'de jure' owners, the state. This exposes wetlands to multi-institutional management since central government departments, local district authorities, traditional authorities, private players, non-governmental organisations (NGOs) and local people participate in wetland management at the same time. Therefore, there is a need to understand the effect of synergies existing between the various players on the ecological condition of wetlands (Chandra, 2011). This is important in light of observations by Russi et al. (2013) that action at all levels and by all stakeholders is needed if the opportunities and benefits of working with wetlands are to be fully realised and the consequences of continuing wetland loss appreciated and acted upon.

In Zimbabwe research information has been lagging behind on how institutions have been evolving, as a way of strengthening institutional performance and their effect. This research will therefore add information to the existing body of knowledge on wetlands in Zimbabwe which Frenken and Mharapara (2002) viewed as inadequate for meaningful planning and decision making. This article assesses the nature and consequences of the prevailing institutional arrangements towards sustainable management of wetland resources in three rural districts of Zimbabwe. Research data were collected using questionnaires which were administered to households selected using a stratified random sampling technique and sixty purposely selected teenagers and key informants representing stakeholder institutions in wetlands governance. The study revealed that several institutions including government departments are involved in wetland management although the compositions of institutional structure vary from wetland to wetland. This resulted in the degree of wetland protection varying from wetland to wetland. The results of the study suggest the need to develop an institutional framework where roles, responsibilities and co-ordination of different institutions are clearly defined. Proposals are made in this paper on ways in which the governance structure of communal wetlands in Zimbabwe can be improved. Other developing countries where wetlands are managed under communal tenure systems should also benefit.

This article is structured as follows: Section 1 is an introductory literature review which highlights the importance of examining institutional arrangements in Zimbabwe, emphasizing the knowledge gap forming the motivation for carrying out this research. Section 2 provides a description of the study area and also outlines the methods of data collection and analysis. In Section 3, the research findings are presented and discussed. Finally, Section 4 concludes the study and highlights the implications of the research for wetland policy, especially in Zimbabwe.

\subsection{Materials and methods}

\subsection{Description of the study area}

The study focuses on six wetlands found in the Tongogara, Runde and Vungu rural districts located on the southern part of Midlands province, Zimbabwe (Fig. 1). The wetlands of interest are Dufuya and Madigane (Vungu), Guruguru and Tugwi (Tongogara) and Chebvuterambatemwa and Zungwi (Runde). The selected wetlands are used for different purposes by local communities, although cultivation dominated. In brief, the study included wetlands exhibiting different ecological states, that is, relatively pristine wetlands and those that are degraded. The focus is on understanding the role played by existing institutional arrangements in managing the resource in the three districts with different agro-ecological conditions and population characteristics. The chosen districts are also inhabited by people who belong to the major ethnic groups in the country, Shona and Ndebele; hence the research findings can be useful to the whole country where wetlands are used under different socio-cultural contexts. 
Fig. 1: Map showing location of wetlands in three rural districts of Zimbabwe

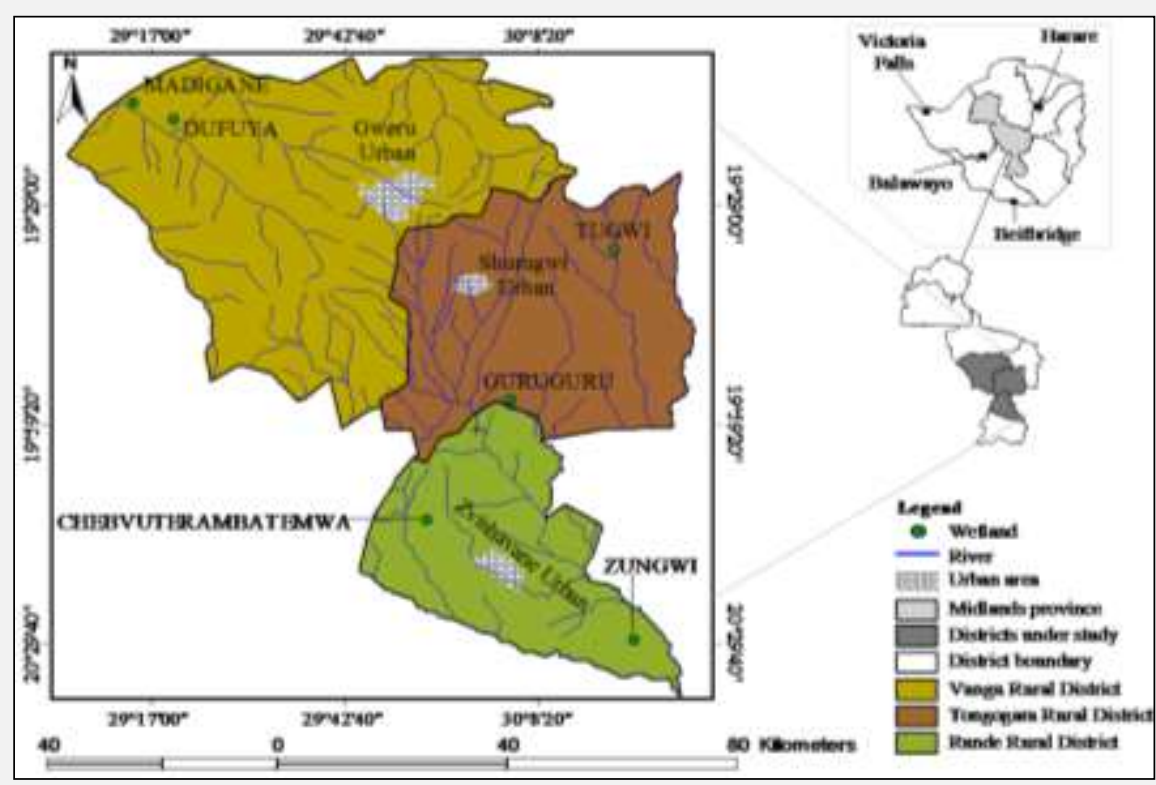

Zimbabwe is divided into five agro-ecological zones, (or natural regions), on the basis of the rainfall regime, soil quality and vegetation (Vincent \& Thomas, 1960; Mugandani et al., 2012). Tongogara rural district (RDC) is located in natural region three, with an average rainfall total ranging from 650-800 $\mathrm{mm}$ per annum. Vungu and Runde rural districts are found in natural region four, receiving an annual average rainfall of 450-650 $\mathrm{mm}$ (Vincent \& Thomas 1960; Mugandani et al., 2012). The three districts experience periodic seasonal droughts, prolonged mid-season dry spells and an unreliable start to the rainy season. The prevailing semi-arid conditions, combined with frequent droughts, affects crop productivity and food security (Mugandani et al., 2012). The climatic conditions oblige smallholder farmers to grow drought-tolerant varieties of maize, sorghum, pearl millet and finger millet, although the risk of crop failure is high (Mugandani et al., 2012). Irrigation plays an important role in sustaining crop production (FAO and SAFR, 2000). Inadequate and poorly developed irrigation infrastructure increases the local communities' dependence on wetlands as they endeavour to improve their livelihood security (FAO, 2006).

Luvisols derived from underlying granite rock are the predominant soil type in Runde RDC and have low pH (FAO, 2006). Deep Kalahari soils (arenosols), with low pH are widespread in both Tongogara and Vungu RDCs (Madebwe and Madebwe, 2005; FA0, 2006). Savannah grassland ecosystem characterised by sparse Brachystegia, Terminalia and Julbernadia tree species dominate the districts under study (Ngorima, 2006; Matsa and Muringaniza, 2011; Marambanyika et al., 2012). The average household size in the three districts is 4.6 persons (Zimstat, 2012). Subsistence farming is the backbone of livelihoods in the three rural districts, albeit local people engage in short contract work (piece-jobs), gold panning and livestock rearing (Ngorima, 2006; Matsa and Muringaniza, 2011) on an occasional basis.

\subsection{Data collection}

The institutions involved in the utilization, management and conservation of wetlands were identified from relevant policy documents, interviews and questionnaires. A total of 123 households were selected using a stratified random sampling technique to respond to questionnaires. The household survey targeted $10 \%$ of households from each of the six wetlands studied (Table 1). The sample size ensured acceptable representation of the target population (Nyariki, 2009). The households selected are utilizing the wetland and/or are aware of the wetland's utilization, management and conservation history. A preliminary baseline survey of the study area was carried out to identify households with the aforementioned attributes. Local leaders assisted researchers to compile registers of households with the desired characteristics and these formed the sampling frame at each wetland site. Simple random sampling of households from each wetland site was done following the rules of random number tables (Dettori, 2010). The survey targeted household heads for questionnaires or in the event of their absence, the eldest household member responsible for making decisions. 


\begin{tabular}{llrrr}
\hline & Table 1: Sampling sites and sample size for households questionnaire survey \\
\hline $\begin{array}{l}\text { Rural } \\
\text { District }\end{array}$ & Wetland name & $\begin{array}{r}\text { Number of villages } \\
\text { around each } \\
\text { wetland }\end{array}$ & $\begin{array}{r}\text { Total number of } \\
\text { households in the villages }\end{array}$ & $\begin{array}{r}\text { Total number of } \\
\text { households } \\
\text { selected }\end{array}$ \\
\hline Vungu & Dufuya & 6 & 199 & 20 \\
Vungu & Madigane & 7 & 280 & 28 \\
Tongogara & Tugwi & 7 & 111 & 11 \\
Tongogara & Guruguru & 5 & 172 & 17 \\
Runde & Chebvuterambatemwa & 9 & 246 & 25 \\
Runde & Zungwi & 8 & 223 & 22 \\
Total & & 42 & 1231 & 123 \\
\hline
\end{tabular}

The household heads' questionnaire captured information on socio-demographic characteristics of households including family size, duration of stay, period of wetland use, location distance from the wetland, and household head age and gender. It was also designed to gather information on households' perceptions on the number, nature and roles of institutions participating in wetland management, inter-institutional relations, the effect of existing institutional arrangements on the ecological conditions of wetlands and proposed reforms to improve institutions' participation in conservation of wetlands and their resources. Some of the questions asked include: Who regulate access to wetland utilization? Who influences management and conservation decisions in the wetland? Are the various institutions involved in wetland use and management very clear about their roles? Is there any conflict among the formal institutions involved in wetland use and management? Lastly, households were asked if at all they participated in wetland conservation and in what way(s) under the existing institutional arrangement.

A total of sixty teenagers, ten from each wetland area, were purposively selected from the above mentioned households with heads included in the survey to answer questions on a second questionnaire. Teenagers were chosen as the future custodians of the resource as they are often engaged in wetland cultivation alongside their parents/guardians. The participation of teenagers in the survey depended on their availability and subject to permission granted by their custodians. A questionnaire for teenagers gathered information on their knowledge of existing institutions and their usefulness in wetland management. Some of the questions asked include: Which institutions are involved in wetland management? Do they make valuable contributions?

The two questionnaires were pre-tested at a different wetland with similar use and population characteristics in order to determine their validity and reliability prior to the main survey being undertaken. The field test was conducted with ten household heads and five teenagers as these two categories represented the target population for questionnaires. Improvements were made to the questionnaire basing on feedback from participants. The questionnaires were translated into local languages and self-administered by the researchers and trained research assistants in order to enhance the rate of return. Research participants' consent and permission from local authorities was sought before questionnaires administration and key informant interviews so as to comply with the conditions of ethical approval by the Humanities and Social Sciences Research Ethics Committee, University of KwaZulu Natal (Reference: HSS/0735/014D).

In addition to household surveys, semi-structured interviews were conducted with key informants (Environmental Management Agency (EMA), Agricultural Technical and Extension Services (Agritex), rural district councils, politicians and traditional leadership) on their role in wetland management and how each relate with other interested and participating institutions. The EMA is the legally designated national body responsible for overseeing management of all natural resources at all levels, including community level. It was imperative to understand how the organization functions in executing its mandate including challenges in regulating certain forbidden activities in wetlands such as cultivation which is widespread.

Each rural district council has an environmental division responsible for management (as the custodian of all natural resources including wetlands at local level). Therefore, it was important to understand how its efforts complemented initiatives of other participating institutions, including national bodies and non-governmental organizations. Agritex, a government department which provide technical advice to farmers, including those working in wetlands was selected to solicit information on wetland utilisation and management since cultivation was practiced in all surveyed wetlands. Councillors, (who are elected political figures representing the government at ward level in districts), were interviewed to gather information on rules governing wetland utilization and management since they are responsible for developing by-laws used in local wetland regulation.

Twelve village heads (representing $28.6 \%$ of the 42 villages' traditional leadership) were chosen based on their age and length of service, as these attributes had a bearing on the wealth of knowledge possessed on temporal 
institutional interactions and change. Two elderly eloquent people above the age of 70 were chosen using a snowball sampling technique in order to tap their institutional memory of wetland resources management structures. Snowball sampling is a technique which relies on referrals to identify other concealed potential target subject(s) (Bryman 2008). In this case, the elderly people constituted a small proportion of the people in the areas studied; hence the researchers engaged village heads to identify the first elderly person who later referred the interviewers to their contemporaries.

\subsection{Data analysis}

Questionnaire data was coded and analysed in the Statistical Package for Social Scientists Version 16 for Windows. Statistical analyses were done at 95\% Confidence Interval. A non-parametric Chi-Square test was used to determine the nature of association between household heads' socio-demographic characteristics (age and marital status of head, size, duration of stay, location) and households' knowledge of participating institutions and their frequency.

Descriptive statistics were used to show frequencies of responses from households for various attributes. Qualitative data obtained from key informant interviews was analysed through thematic analysis. This method was used to identify, analyse and report themes, which are patterns across data sets that are important to the description of a phenomenon (Braun and Clarke, 2006). Themes were drawn on the roles of different institutions; challenges encountered under the existing institutional set-up and proposed measures to ameliorate wetland management among other study variables.

\subsection{Results and discussion}

\subsection{Socio-demographic information of household participants}

A total of $91.9 \%$ of the respondents, mostly married (71.5\%) are unemployed compared to self-employed (4.9\%) and formally employed (3.2\%). Dependence on wetlands is high as $97 \%$ of the households relied on wetland provisioning services such as water, food and medicine as classified by the Millennium Ecosystem Assessment (2005).

There is a good balance of men (51.2\%) and women (48.8\%) in wetland management despite the patriarchal nature of the communities. The duration of stay of each household in the area is on average three decades (Table 2). This is mainly influenced by the household head's place of birth and migration. The duration of stay, however, shows that the people had extensive knowledge of the existing institutions involved in wetlands.

Table 2: Socio-demographic information of households

\begin{tabular}{lrr} 
& Table 2: Socio-demographic information of households & Standard deviation* \\
\hline Attribute & Mean & 2.78 \\
Household size & 5.9 persons & 1.59 \\
Age group & $46-55$ & 20.22 \\
Period stayed in the area (years) & 33.55 & 12.43 \\
Period of using the wetland (years) & 8.81 & 870.07 \\
Distance travelled (meters) & 1209 & 18.25 \\
Approximate travel time (minutes) & 23.39 & \\
$*$ The larger the size of the deviation, the greater variation in responses on the measured attributes.
\end{tabular}

On average, households have been using wetlands for nine years (Table 2). Chi-Square test results further confirms that no association $(\mathrm{p}=0.11)$ existed between duration of stay by each household in the area and the period each household has been using the wetland. This means local people commenced wetland use, especially for cultivation, at different times (Table 2). Wetland utilization is mainly voluntary and sometimes influenced by NGOs which implement wetland-based food security projects. On average households walk $1.2 \mathrm{~km}$ to the wetland, a distance which take an average of 24 minutes. Population size of 5.9 persons in households around wetlands is higher than the 4.6 mean household size in the three districts. Wilcoxon Signed rank test results show that community dependence on wetlands is high as the difference between average total wetland income and average total household income is statistically insignificant $(p=0.001)$. This means a large proportion of household income is drawn from wetlands. High population densities were also observed around Lake Victoria (Musamba et al., 2011), an indicator that wetlands are an important source of livelihoods in rural communities of Africa as a whole.

\subsection{Wetland ownership}


There are differences in households' views of wetland ownership. Given the existence of the communal tenure system, which is premised on open access, most households (66.7\%) and $85 \%$ of teenagers indicate that the wetlands belong to the local people (Table 3). Most local residents' perceptions are at variance with the legal position in the country that wetlands, just like any other natural resource in communal areas, belong to the state and are supposed to be administered through local authorities and traditional leaders.

Local communities therefore either confused user rights with ownership, or mistook administration rights of local authorities for ownership. The differences in community perceptions on ownership is attributed by local authorities and government agencies to lack of knowledge by local people on the requirements of communal resource tenure system, which gives local people user rights only. Property rights issues in wetlands are therefore marred by confusion, a situation with potential to cause management tensions. Some key informants further revealed that local people sometimes resist management advice from government departments as it is perceived as unnecessary external interference on their private property.

Table 3: Households' views on wetland ownership, as measured by responses to a questionnaire survey

\begin{tabular}{|c|c|c|c|c|c|c|c|c|c|c|c|c|c|c|}
\hline \multirow[t]{2}{*}{ Institution } & \multicolumn{2}{|c|}{$\begin{array}{l}\text { Madigane } \\
\quad(n=28)\end{array}$} & \multicolumn{2}{|c|}{$\begin{array}{l}\text { Dufuya } \\
(n=20)\end{array}$} & \multicolumn{2}{|c|}{$\begin{array}{r}\text { Chebvute } \\
(n=25)\end{array}$} & \multicolumn{2}{|c|}{$\begin{array}{l}\text { Tugwi } \\
(n=11)\end{array}$} & \multicolumn{2}{|c|}{$\begin{array}{l}\text { Zungwi } \\
(n=22)\end{array}$} & \multicolumn{2}{|c|}{$\begin{array}{r}\text { Guruguru } \\
\quad(\mathrm{n}=17)\end{array}$} & \multicolumn{2}{|c|}{$\begin{array}{r}\text { Total } \\
\text { respondents } \\
(n=123)\end{array}$} \\
\hline & $\mathrm{F}$ & $\%$ & $\mathrm{~F}$ & $\%$ & $\mathrm{~F}$ & $\%$ & $\mathrm{~F}$ & $\%$ & $\mathrm{~F}$ & $\%$ & $\mathrm{~F}$ & $\%$ & $\mathrm{~F}$ & $\%$ \\
\hline $\begin{array}{l}\text { Traditional } \\
\text { leaders }\end{array}$ & 6 & 21.4 & 3 & 15 & 7 & 28 & 2 & $\begin{array}{r}18 . \\
2\end{array}$ & 2 & 9 & 2 & 11.8 & 22 & 17.9 \\
\hline Local people & 16 & 57.1 & 14 & 70 & 15 & 60 & 11 & 100 & 13 & 59.1 & 13 & 76.5 & 82 & 66.7 \\
\hline $\mathrm{RDC}$ & - & - & 1 & 5 & 2 & 8 & 1 & 9.1 & - & - & 5 & 29.4 & 9 & 7.3 \\
\hline $\begin{array}{l}\text { Central } \\
\text { government }\end{array}$ & 9 & 32.1 & 8 & 40 & 1 & 4 & 1 & 9.1 & 1 & 4.5 & - & - & 20 & 16. \\
\hline God & 1 & 3.5 & - & - & - & - & - & - & - & - & 1 & 5.9 & 2 & 1.6 \\
\hline Don't know & 4 & 14.3 & 1 & 5 & - & - & - & - & 1 & 4.5 & 2 & 11.8 & 8 & 6.5 \\
\hline
\end{tabular}

F-Frequency; "-" - represents no responses. No response indicates that the institution or entity is not known or operating in that area.

Research results in communal areas of Zimbabwe on wetland ownership are reminiscent to findings in Uganda where property rights were poorly defined, a situation which is associated with unsustainable practices leading to wetland degradation (Maclean et al., 2009). Therefore, there is a need for ownership clarification for the good of wetland conservation as there is considerable ambiguity surrounding the concept of government or local authorities holding wetlands in trust for the people, a view also upheld by Maclean et al. (2009).

\subsection{Wetland governance structure}

Wetland resource use, management and conservation in communal areas embraces a multi-sectoral approach. The whole process is driven by several institutions including local institutions controlled by traditional leaders and wetland committees and external institutions such as local and central government agencies and NGOs (Fig. 2). Some institutions are mainly involved in wetland use (Agritex), conservation (RDC and EMA) or both (NGOs, traditional leaders and wetland committees). The way in which different institutions participate is influenced by diverse institutional mandates and priorities torn between socio-economic and environmental considerations.

Although $80.5 \%$ of household heads indicated that institutions are clear on their wetland management and conservation roles, the number, significance and purpose of institutions operating at each wetland site is inconsistent (Table 4 and 5). Lack of uniformity of institutional structure at communal level result in wetland destruction as in the case of Chebvuterambatemwa and Zungwi as evidenced by wetland degradation whose extent and magnitude depended on the installed management system as noted by most key informants. This scenario complements Moses (2008) and Zsuffa et al. (2014)'s observations, namely that a complex situation where different partners operate in coalition requires co-ordination for effective management of wetlands. Successive sections of this study will discuss how the multi-sectoral approach functions in wetland utilization, management and conservation in communal areas. 
Fig. 2 Stakeholder participation in communal wetlands governance

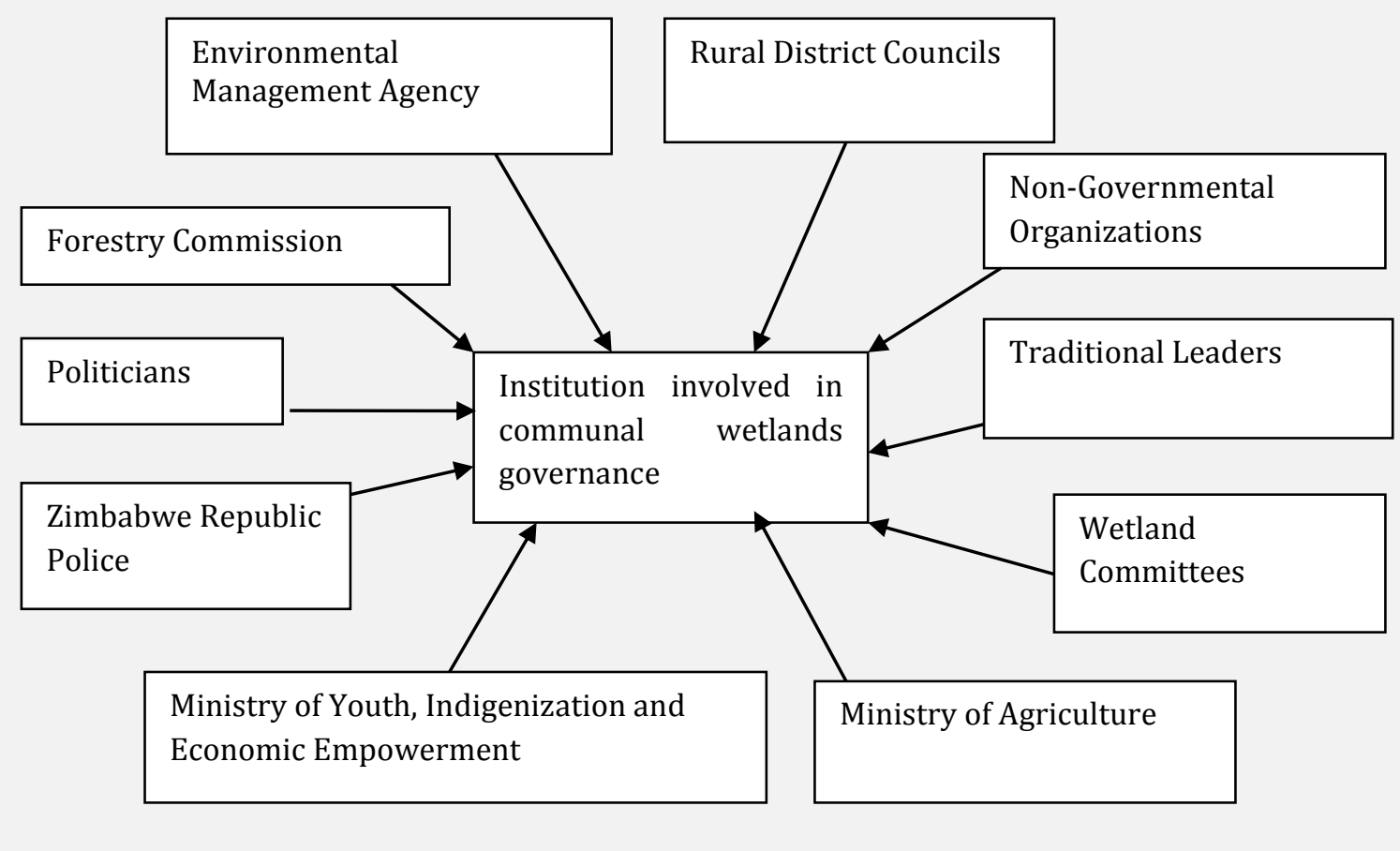

\subsubsection{The role played by different institutions in wetland access and utilization}

Variations were noted regarding the contribution of different institutions in regulating access and use of wetlands (Table 4). Most households (69.1\%) indicate that traditional leaders are playing a dominant role in allocating cultivation plots to local residents. The participation of traditional leaders is in tandem with stipulations in the Traditional Leaders' Act (1998) that empower them to regulate access by people to natural resources in their areas of jurisdiction.

\begin{tabular}{|c|c|c|c|c|c|c|c|c|c|c|c|c|c|c|}
\hline \multirow{3}{*}{ Institution } & \multirow{2}{*}{\multicolumn{2}{|c|}{$\begin{array}{r}\text { Madigane } \\
(\mathrm{n}=28)\end{array}$}} & \multirow{2}{*}{\multicolumn{2}{|c|}{$\begin{array}{l}\text { Dufuya } \\
(\mathrm{n}=20)\end{array}$}} & \multirow{2}{*}{\multicolumn{2}{|c|}{$\begin{array}{r}\text { Chebvute } \\
(\mathrm{n}=25)\end{array}$}} & \multirow{2}{*}{\multicolumn{2}{|c|}{$\begin{array}{l}\text { Tugwi } \\
(n=11)\end{array}$}} & \multirow{2}{*}{\multicolumn{2}{|c|}{$\begin{array}{l}\text { Zungwi } \\
(\mathrm{n}=22)\end{array}$}} & \multirow{2}{*}{\multicolumn{2}{|c|}{$\begin{array}{r}\text { Guruguru } \\
(n=17)\end{array}$}} & \multirow{2}{*}{\multicolumn{2}{|c|}{$\begin{array}{r}\text { Total } \\
\text { respondents } \\
(n=123)\end{array}$}} \\
\hline & & & & & & & & & & & & & & \\
\hline & $\mathrm{F}$ & $\%$ & $\mathrm{~F}$ & $\%$ & $\mathrm{~F}$ & $\%$ & $\mathrm{~F}$ & $\%$ & $\mathrm{~F}$ & $\%$ & $\mathrm{~F}$ & $\%$ & $\mathrm{~F}$ & $\%$ \\
\hline Traditional leaders & 15 & 53.6 & 19 & 95 & 15 & 60 & 11 & 100 & 15 & 68.2 & 10 & 58.3 & 85 & 69.1 \\
\hline Political leaders & 10 & 35.7 & 1 & 5 & 6 & 24 & - & - & - & - & - & - & 17 & 13.8 \\
\hline EMA & 3 & 10.7 & 1 & 5 & 9 & 36 & 4 & 36.4 & 4 & 18.2 & - & - & 21 & 17.1 \\
\hline Agritex & 14 & 50 & 8 & 40 & 8 & 24 & - & & 9 & 40.9 & 4 & 23.5 & 43 & 35 \\
\hline $\mathrm{RDC}$ & 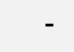 & & & & 7 & 28 & 2 & 18.2 & 7 & 31.8 & 4 & 23.5 & 20 & 16.3 \\
\hline Local people & 1 & 3.5 & 1 & 5 & - & - & - & - & - & - & - & - & 2 & 1.6 \\
\hline Wetland committee & - & - & - & - & 4 & 16 & - & - & 3 & 13.6 & 1 & 5.9 & 8 & 6.5 \\
\hline $\begin{array}{l}\text { Mechanization } \\
\text { Division }\end{array}$ & - & - & - & - & - & - & 3 & 27.3 & - & - & - & - & 3 & 2.4 \\
\hline NGOs & 15 & 53.6 & 13 & 65 & 16 & 64 & 4 & 36.4 & 10 & 45.5 & 2 & 11.8 & 62 & 50.4 \\
\hline Don't know & - & - & - & - & 4 & 16 & 1 & 9.1 & - & - & 2 & 11.8 & 7 & 5.7 \\
\hline
\end{tabular}

F-Frequency; "-" - represents no responses, which shows that the institution was not known or participating in that area.

Meanwhile, Agritex demarcates farming plots in and around wetlands and sometimes assist NGOs in the allocation of farming inputs used in wetland cultivation such as seeds and agrochemicals. Agritex therefore influences the number of people accommodated in wetland cultivation, which is the primary land use activity. NGOs such as Heifer International and Care also promoted wetland utilization by facilitating production training in partnership with Agritex, providing material (such as fence), financial assistance and market linkages to wetland farmers. Some livelihood activities promoted by NGOs include cultivation, fisheries and apiculture. 
Only $17.1 \%$ of households revealed that EMA regulates access to wetland utilization. This may explain why according to EMA no single wetland is utilized for cultivation with a permit as required by the EMA Act (2003) (Subsection 113) and Statutory Instrument (S.I.) 7 of 2007 (Environmental Impact Assessment and Ecosystems Protection) Subsection 20 (1). These statutes expect EMA to grant licences to prospective wetland users having a clear environmental management plan for certain activities, regardless of the scale of operation. This position concurs with Dixon (2005) findings that most developing countries do not openly support wetland utilization and development despite their role in livelihood security. The use of wetlands with the participation of different institutions is therefore mainly driven by the need to enhance household food security. Furthermore, local and central government agencies revealed that they are handicapped by politics which makes it difficult for them to evict illegal wetland users whose basic livelihoods are dependent on the resource.

Moreover, councillors breach wetland law by sanctioning encroachment of gardens into the wetland core in violation of wetland law and expectations of local tradition and custom. This is common in Madigane. The wetland core is the preserved area which is not supposed to be disturbed by human activities such as cultivation and livestock grazing since it is viewed as a scared permanent source of water. However, a study by Clare and Creed (2014) revealed that the use of wetlands without government permits even resulted in significant degradation of the resource in Canada. Therefore continued use of wetlands without clear environmental management plans could be a threat to wise use of the resource as adequate monitoring can be a challenge, a situation already observed to be happening in Madigane wetland.

Wetland committees which are elected by wetland beneficiaries (who are local people) also directly regulate day to day use of the resource in Chebvuterambatemwa and Tugwi as revealed by $6.5 \%$ of households. The locally organised committees determine the number of people accommodated by each wetland by approving new applicants in consultation with traditional leaders and Agritex. Meanwhile, ward youth officers, operating under the Ministry of Youth, Indigenization and Economic Empowerment promote participation of more youth in wetland use as a strategy to empower them for better lives as championed in the country's economic blueprint, Zimbabwe Agenda for Sustainable Socio-Economic Transformation (2013 - 2018). Youth officers ensure that at least $30 \%$ of farming plots are allocated to youth as in the case of Tugwi. Therefore, the abovementioned institutional arrangements revealed that, with the exception of EMA, other local and external institutions directly or indirectly promote wetland utilization in various ways. This result explains why $94.3 \%$ of households' revealed that there was no conflict between formal institutions involved in regulation of wetland use.

\subsubsection{The role of different institutions in wetland management and conservation}

The EMA and traditional leaders are key stakeholders influencing policy direction on wetland management and conservation, although other institutions (Agritex, Forestry Commission, NGOs, RDCs, Wetland committees,) play peripheral but omnipotent roles at specific wetland locations (Table 5). Although the EMA seldom participates in wetland conservation through education, awareness, monitoring of legal adherence, initiating wetland protection projects (e.g. Chebvuterambatemwa) and monitoring illegal extension of farming plots, the institution is well known to local communities due to its punitive measures to degrading activities, including a jail sentence, as confirmed by $42.2 \%$ of household respondents and $71.7 \%$ of teenagers. Traditional leaders monitor wetland abuse by checking local people's compliance to local policies such as illegal expansion of cultivation plots and uncontrolled burning and often punish the culprits. The effectiveness of traditional leaders is attributed by $52 \%$ of the households to their closeness to the people cemented by kinship ties and mutual respect for existing social relations.

The Forestry Commission's activities are mainly confined to catchment management where they monitor vegetation cover. This situation according to $87.8 \%$ of surveyed households and $23.3 \%$ of the teenagers enhances catchment protection as deforestation and sediment load into the wetlands is reduced. The conservation of catchment area is critical, given observations that its degradation contributes to wetland loss (Macfarlane et al., 2007; Marambanyika et al., 2016). In Dufuya and Chebvuterambatemwa wetlands, councillors monitor illegal activities (such as drilling of several wells, garden encroachment) and co-ordinate community meetings facilitated by NGOs and government departments on sustainable wetland utilization practices. 
Table 5: Households' views on the degree of influence by institutions in wetland management and conservation decisions (as measured by responses to questionnaire survey)

\begin{tabular}{|c|c|c|c|c|c|c|c|c|c|c|c|c|c|c|}
\hline \multirow[t]{2}{*}{ Institution } & \multicolumn{2}{|c|}{$\begin{array}{r}\text { Madigane } \\
(n=28)\end{array}$} & \multicolumn{2}{|c|}{$\begin{array}{l}\text { Dufuya } \\
(n=20)\end{array}$} & \multicolumn{2}{|c|}{$\begin{array}{r}\text { Chebvute } \\
(n=25)\end{array}$} & \multicolumn{2}{|c|}{$\begin{array}{l}\text { Tugwi } \\
(n=11)\end{array}$} & \multicolumn{2}{|c|}{$\begin{array}{l}\text { Zungwi } \\
(n=22)\end{array}$} & \multicolumn{2}{|c|}{$\begin{array}{r}\text { Guruguru } \\
(\mathrm{n}=17)\end{array}$} & \multicolumn{2}{|c|}{$\begin{array}{r}\text { Total } \\
\text { respondents } \\
(n=123)\end{array}$} \\
\hline & $\mathrm{F}$ & $\%$ & $\mathrm{~F}$ & $\%$ & $\mathrm{~F}$ & $\%$ & $\mathrm{~F}$ & $\%$ & $\mathrm{~F}$ & $\%$ & $F$ & $\%$ & $\mathrm{~F}$ & $\%$ \\
\hline $\begin{array}{l}\text { Traditiona } \\
\text { l leaders }\end{array}$ & 20 & 71.4 & 13 & 65 & 10 & 40 & 7 & 63.6 & - & - & 1 & 5.9 & 51 & 41.5 \\
\hline Councillor & 9 & 32.1 & 3 & 15 & 4 & 16 & 1 & 9.1 & - & - & - & - & 17 & 13.8 \\
\hline $\mathrm{RDC}$ & 2 & 7.1 & 4 & 20 & 4 & 16 & 1 & 9.1 & - & - & 2 & 11.8 & 13 & 10.6 \\
\hline $\begin{array}{l}\text { Wetland } \\
\text { committee }\end{array}$ & 4 & 14.3 & 2 & 10 & 13 & 52 & 1 & 9.1 & 2 & 9.1 & 2 & 11.8 & 24 & 19.5 \\
\hline EMA & 15 & 53.6 & 9 & 45 & 15 & 60 & 9 & 81.8 & 4 & 18.2 & - & - & 52 & 42.2 \\
\hline Agritex & 5 & 17.9 & 3 & 15 & 8 & 32 & 4 & 36.4 & 10 & 45.5 & 7 & 41.2 & 37 & 30 \\
\hline $\begin{array}{l}\text { Research } \\
\text { institution } \\
\text { S }\end{array}$ & - & - & - & - & - & - & - & - & 1 & 4.5 & 2 & 11.8 & 3 & 2.4 \\
\hline $\begin{array}{l}\text { NGOs } \\
\text { Forestry } \\
\text { Commissio } \\
\mathrm{n}\end{array}$ & $\begin{array}{l}4 \\
-\end{array}$ & $\begin{array}{r}14.3 \\
-\end{array}$ & $\begin{array}{l}2 \\
-\end{array}$ & $\begin{array}{r}10 \\
-\end{array}$ & $\begin{array}{r}1 \\
10\end{array}$ & $\begin{array}{r}4 \\
40\end{array}$ & $\begin{array}{l}- \\
-\end{array}$ & - & - & 9.1 & $\begin{array}{l}1 \\
-\end{array}$ & $\begin{array}{r}5.9 \\
-\end{array}$ & $\begin{array}{r}8 \\
13\end{array}$ & $\begin{array}{r}6.5 \\
10.6\end{array}$ \\
\hline
\end{tabular}

Agritex equips wetland users with knowledge on sustainable wetland utilization by promoting adoption of conservation farming techniques, since erosion was identified to be a major cause of wetland degradation (Whitlow, 1989). In Chebvuterambatemwa, Dufuya, Madigane and Tugwi wetlands, basin tillage and compositing are encouraged, although they are not wholly embraced by all farmers. However, some farmers use ox-drawn ploughs in land preparation so as to reduce labour demand for weeding. This practice was observed to increase the chances of soil erosion in wetlands (Kotze, 2011).

Non-governmental organizations on the other hand provide cash-strapped communities with material resources (such as fences) to prevent wetland degradation by livestock, especially through cattle trampling. Given the prevailing semi-arid conditions, wetlands are observed to provide water and pasture to livestock. Nevertheless, cattle trampling is reported by $9.8 \%$ household heads and $26.7 \%$ teenagers to be responsible for desiccation in unprotected wetland sections. The effect of cattle trampling on wetlands was also well studied (Sibanda, 2005; Dahwa et al., 2013; Morris and Reich, 2013).

Wetland committees, with the assistance of users, guard wetlands, apprehend illegal users and report illegal activities to relevant government agencies. Some prohibited activities mentioned by households include hunting, cutting of thatch grass and trees, digging worms, extension of gardens beyond demarcations set by Agritex and EMA and fence vandalism. However, poor coordination of wetland management by committees in Guruguru and Zungwi is perceived by farmers to be responsible for the deterioration of wetland conditions. The role of wetland committees in coordinating wetland management activities and spatio-temporal variations in their performance was also acknowledged in Ethiopia (Dixon, 2005). Therefore, almost all institutions assist wetland users to utilize wetlands in a way that somehow promotes their conservation through a variety of strategies. The performance of the EMA is, however, affected by inadequate resources, and this underscores the need to improve its performance given its potential to effectively regulate human activities in wetlands.

\subsubsection{Frequency of institutions participation in wetland use and management}

Traditional leaders are more visible in both wetland use and management, as they work with local people more than EMA, RDCs and NGOs (Fig. 3). The high frequency of traditional leaders is influenced by the fact that they live close to the people and wetlands. Some $60.1 \%$ of households have commented on the low frequency of the visits by the EMA. The consequence is that their wetland management is more reactive rather than proactive. The EMA occasionally responds to wetland degradation threats such as fire instead of routine management of the resource. Despite having a department responsible for environmental conservation, the presence of the RDCs is negligible. Therefore, inadequate participation of local and national government institutions compromise their effective participation in sustainable wetland management as they remain largely invisible. Poor participation of government departments is not only a problem in these wetlands of rural Zimbabwe but was also common in Ethiopia (Dixon et al., 2013). The proper functioning of RDCs and EMA is constrained by 
inadequate human and financial resources resulting in their sporadic visits. In contrast, Agritex is involved more frequently in wetland cultivation, as it interacts with wetland users almost on a daily basis. This is attributed to the institution's operations at micro-level (i.e. ward-based) in promoting food security compared to EMA whose operations on environmental management are centralised at district level.

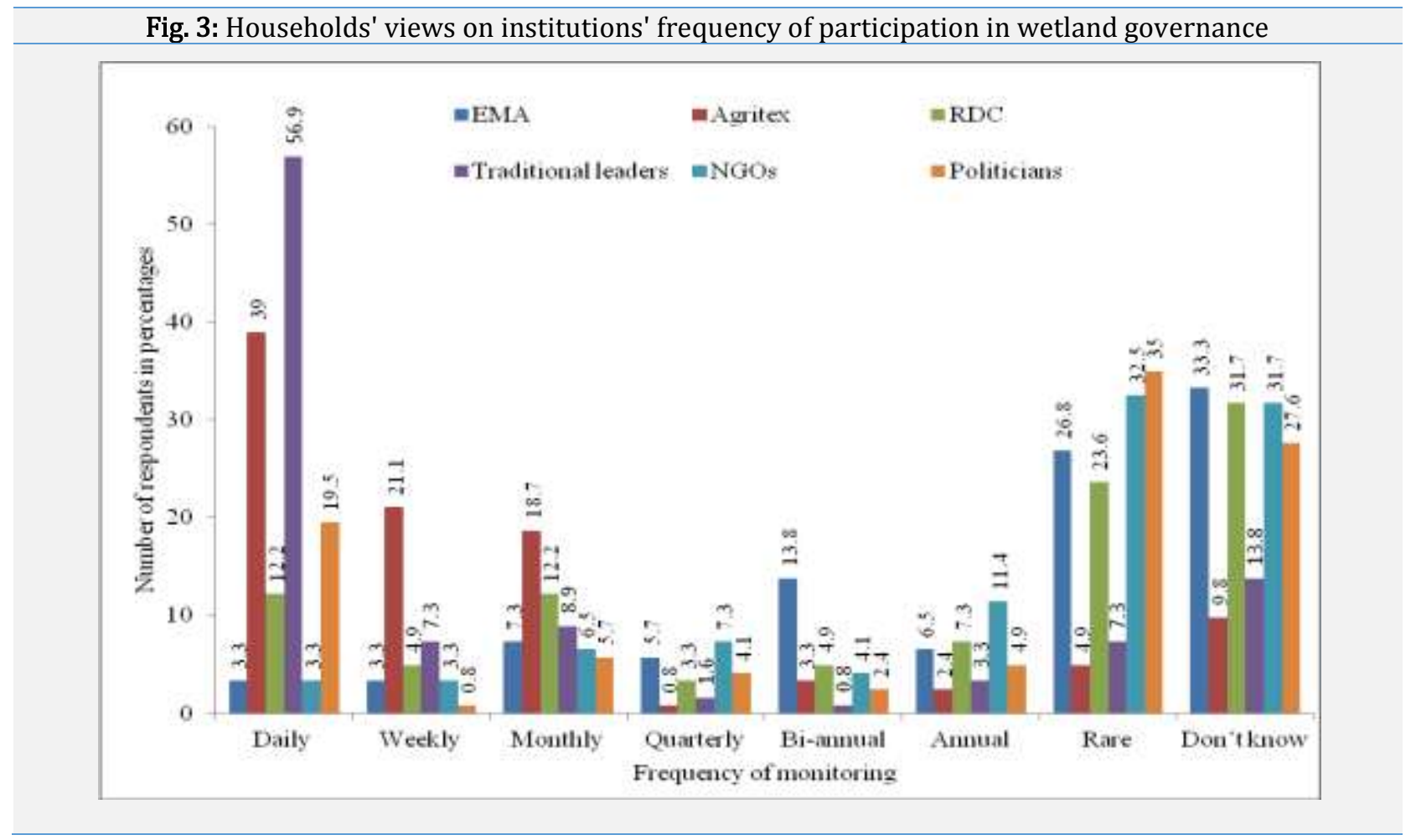

The significance of political leaders and NGOs is restricted to specific wetlands (Table 4 and 5). For instance, NGOs participated at the initial stages of project development and implementation and taught local people wise use strategies when donor funding was still available. Wise use is basically maintenance of a wetland's ecological character whilst safeguarding human interests (Ramsar Convention Secretariat, 2010). Therefore, in Guruguru and Zungwi wetlands, the departure of NGOs resulted in wetland degradation as local communities mismanaged the sustainable cultivation technique implemented as confirmed by $9.8 \%$ of household heads. It was also noted that councillors effectively participate in wetland conservation where they stay closer to wetlands and access benefits. This may explain why councillors are largely unknown in most wetlands, except in Madigane. In a nutshell, the frequency of participation in wetland management and conservation by EMA, RDCs and NGOs is poor despite observations by Mwakubo and Obare (2009) that the number of visits by institutions is a significant determinant of the willingness of local people to participate in sustainable wetland conservation.

\subsubsection{Relationship between different management institutions}

The relationship is defined by the linkages and interactions between the various stakeholders in wetlands. The way in which institutions relate in wetlands management is critical as a harmonious approach normally benefits the resource through conservation due to elimination of existing or potential conflicts as revealed by all key informants and $83.7 \%$ of households. The involvement of more than one institution at each wetland site result in either complementary or contradictory roles. Relations are sometimes less cordial due to overlapping and conflicting institutional roles. Generally, traditional leaders, EMA and RDCs consult and complement each other's efforts as they regularly embark on collaborative meetings, workshops and campaigns as confirmed by some key informants and $34.4 \%$ of households.

EMA and RDCs also operate through the same environmental monitors at local level, a situation which assists them to synchronize their operations. Environmental monitors are voluntary individuals who monitor and coordinate natural resources management at ward level. RDCs and EMA sometimes incorporate the Zimbabwe Republic Police (ZRP) when enforcing wetland law and policies. This enables pooling together of meagre resources available for wetland management. Where EMA, RDCs, ZRP and traditional leaders effectively work together, illegal activities in wetlands are reported by some key informants to be low. 
Non-governmental organizations' operations in wetlands are sanctioned by RDCs who in turn monitor their livelihood activities. Nonetheless, NGOs are sometimes at loggerheads with RDCs where they deviate from their approved conditions of operation, thereby endangering wetland ecology by indirectly furthering unsustainable wetland utilization. A case in point is where wetland users in Dufuya were duped by an NGO to enter into contract farming without the knowledge of the RDC. This resulted in farmers expanding cultivation activities into the wetland in an attempt to improve their ultimate net gain. Therefore, little verification of the requirements and follow-up for development projects by local authorities poses challenges in wetland management (Morzaria-Luna et al 2014).

Relations between EMA and NGOs are not always cordial. They often pull in different directions due to divergent institutional motives. EMA mainly focus on wetland conservation whereas NGOs primarily focus on food security through nutrition gardens and livestock production. The role of NGOs in improving agricultural productivity is also acknowledged by Kotze (2011). As each institution executes its mandate, different institutional goals sometimes degenerate into management conflicts as confirmed by $5.7 \%$ of surveyed households, which local people capitalize on their advantage, a situation which poses threats to wetland protection. This was also confirmed by Mbereko (2008) who indicated that local people follow advice from institutions which give them livelihood opportunities like cultivation. However, where NGOs complement EMA's conservation initiatives, relations are good and wetlands are better conserved as in the case of Chebvuterambatemwa and Tugwi. NGOs have mutual relations with Agritex as their focus is largely the same, that is, to increase agricultural production and improve household food security.

Agritex's effective participation in wetland management is compromised by inadequate acknowledgement of their efforts by EMA and RDCs. The attitude of EMA towards Agritex has been changing in some areas, in particular, Chebvuterambatemwa wetland. Where they work together, Agritex and EMA complement each other in wetland conservation as Agritex also monitors and discourages encroachment of gardens into wetland. Wetland committees are present at all sites and are recognised by other institutions involved in wetland management. This was confirmed by $94.3 \%$ of wetland users. Therefore, wetland committees are a vital entity in communal wetland use.

Relations between EMA and councillors are sometimes bad especially where the latter despised EMA's efforts for political reasons. However, a platform has been created whereby institutions like EMA, RDC environmental officers and councillors meet to deliberate on environmental issues including wetlands at district level. Nonetheless, the implementation of agreed resolutions is poor due to divergent institutional goals and priorities. For instance, unlike EMA whose focus is on environmental management, RDCs' mandate is torn between environmental protection and improving livelihoods of the people, with the later given precedence. This result concurs with findings that there are conflicts and trade-offs between livelihood requirements and conservation, as objectives of these two aspects were not always congruent (IWMI, 2014; Island Press, 2007). Although institutional relations in wetland management are partly cordial, co-ordination of institutional activities should be improved to achieve sustainable utilization of wetlands.

\subsubsection{The role of wetland users in wetland management and conservation}

Although $82.1 \%$ of households indicated that they participate in wetland conservation, there are variations in their ways of participation. Conservation activities carried out by surveyed households include maintenance of fences (58.5\%), monitoring of illegal activities in the wetland such as cattle grazing and extension of gardens (72.4\%), conservation farming (54.5\%), catchment protection (7.3\%) and construction of fireguards (3.3\%). The research further examined the extent to which socio-demographic characteristics of households influenced their participation in wetland management and conservation. Chi-Square test results revealed a statistically significant association between marital status $(p=0.03)$, household size $(p=0.00)$ period stayed in the area $(p$ $=0.00)$, period of utilizing the wetland $(p=0.00)$ and distance travelled to wetland $(p=0.00)$ as well as the number of households participating in conservation.

Results of statistical analysis therefore show that residents who live in proximity of and have been utilizing wetlands for a long period participate more in the conservation of the resource, compared to those who recently started to use the resource and those who stay in distant locations. This may be an indicator that these people value wetlands more because they enjoy diverse ecosystem services. Married people participate in conservation activities more than widows and single persons and this also applies to households with large population size. This may be attributed to division of labour since these households have a pool of labour at their disposal. Thus household size, marital status, period of utilizing the wetland, duration of residence and location of a household from the wetland should be considered in planning for wetland management and conservation, as they directly 
influenced local participation unlike age $(p=0.14)$, gender $(p=0.34)$, education level $(p=0.83)$ and employment status $(\mathrm{p}=0.10)$ of the household head.

\subsection{Benefits of the current institutional arrangement to local communities and the wetlands}

The majority of the households (63.4\%) indicated that they are benefiting from wetlands by directly harvesting wetland products or practising agriculture, a situation they attributed to regulation of wetland use by existing institutions. Traditional leaders and wetland committees play an integral role in supporting wetland use activities with the assistance of government departments (e.g. Agritex) and NGOs as discussed earlier. The prevailing governance structure therefore allows wetland users to increase their agricultural yield (as revealed by $54.5 \%$ ) and in some cases expands their livelihood options through fishing and apiculture (4.1\%). This result tallies with that of Mujaju et al. (2013). Wetland benefits in turn act as incentives to protection of wetland ecosystems as in the case of Chebvuterambatemwa, Dufuya, Madigane and Tugwi. For instance, in Madigane, farmers who are allocated wetland plots for gardening monitor protecting fences from vandalism. In this manner, the -incorporation of local people in wetland use assists in sustainable wetland conservation. The existing institutional arrangement to some extent increases co-operation between traditional leaders and government institutions, as they sometimes work towards a common goal of sustainable utilization.

\subsection{Challenges affecting wetland governance under current institutional arrangement}

The major bottleneck to the current institutional structure efforts is lack of co-ordination and the dominance of some institutions. NGOs sometimes use their financial muscle to dominate wetland use and conservation decision making. Absence of a clear institutional framework act as an obstacle to effective wetland governance as institutional duties are not always apparent, as confirmed by $87.8 \%$ households. In some cases, institutions like EMA identify themselves as the sole entity with a mandate to manage wetlands, without acknowledging efforts of other institutions, a position which confuses users when it comes to which institutional advice to follow. The distant location of institutions such as EMA often makes assistance rendered to local communities insignificant as their visits are infrequent. This explains why $5.7 \%$ of households indicated that there is a need to decentralise the EMA's operations to ward level in order to increase its involvement in wetland management.

The current institutional arrangement is also riddled by confusion emanating from differences in institutional dimensions. Different fines are charged by EMA, ZRP, RDCs and traditional leaders for similar wetland offences. Agritex and NGOs are mainly concerned with increasing productivity hence sometimes cannot stop people from engaging in farming practices that degrade wetlands. The differences between institutions lead wetland users to comply with views favourable for them (that is, those which allowed them to engage in activities such as cultivation which give them direct benefits) regardless of their effect on wetland integrity. This may explain why traditional leaders and wetland committees are more popular and accepted by local people than the EMA, which prohibits unauthorised cultivation.

Wetland committees' dictatorial tendencies, (whereby they disregarded views of other wetland users), sometimes result in conflict to the detriment of wetlands. For instance, at Guruguru and Zungwi, the committees did not value wetland management contributions by other users, a situation which brought disharmony and caused subsequent drying of the wetlands due to mismanagement of the implemented cultivation technology, locally known as 'ngwarati'. Politicization of wetland use and management, especially by councillors is another concern which undermines the efforts of government agencies such as the EMA. Access to wetland use is sometimes done on political grounds as it is determined by the political affiliation of individual households. Moreover, the participation of political leaders in most cases is driven more by political ambitions than the need to conserve the wetland, a situation also observed in Nigeria by Adekola et al (2012). Therefore, political interests take precedence ahead of wetland conservation.

There is also inconsistency in wetland policy articulation by the same institution or different institutions involved in wetland management, a situation which leaves wetland users confused on their status in wetland management process. For instance, at Chebvuterambatemwa households which are involved in sustainable wetland utilization with the support of EMA were threatened with expulsion by officials from the same Agency who notified them that they are illegal users. This proclamation was made despite the wetland having been hailed as a symbol of sustainable utilization in Midlands Province in year 2012. This brought disgruntlement among local people, resulting in the commencement of wetland degrading activities. Institutions like Agritex mainly participate in donor funded wetland management projects. This normally brings mistrust and tension as local communities view their motive with suspicion. 
Most problems in wetland governance are shown to emanate from poor co-ordination and a lack of consensus between institutions. Therefore $87.8 \%$ of households indicated that there is need to reform the current institutional set-up. This can be achieved by creating a framework to facilitate institutional meetings where common goals and work plans are drafted so that unity of purpose in wetland conservation can be fostered between all institutions and the local people. There is a need to establish a wetland management department whose mandate is to provide a platform for wetland research, monitoring and information dissemination. The country can achieve this by drawing some lessons from Uganda whose system in wetland governance has been improving over the years (Moses, 2008; Maclean et al., 2009). In Uganda, there is an elaborate institutional arrangement for wetland management, as this responsibility is vested in the Wetlands Inspection Division (Moses, 2008). Furthermore, given multi-institutional involvement in wetland management, for the purposes of co-ordination, the National Wetlands Inter-Agency Co-ordination Committee was established in Uganda and its operations are replicated at both district and local levels.

The establishment of an inter-institutional mechanism to oversee and co-ordinate institutions that governs wetland resources in Zimbabwe will enhance planning, implementation and monitoring of wetland management and conservation. Moreover, local people need to be educated on the role and importance of external institutions in order to minimize conflict between local people and support institutions based on divergent views and expectations. Education will therefore facilitate easy acceptance of external institutions' advice and support; hence improving relations between some institutions and local people. Clarification of institutional mandates through such platform may further iron out confusion amongst people on their roles and relationships. The success of the committee may, however, depend on decentralisation of its operations to local level and provision of resources for their work. The committee should include wetland users, traditional leaders and wetland committees so as to tape on their indigenous knowledge on wetland values and management in their best interest. This recommendation concurs with findings by Jamu et al. (2013) in the Lake Chilwa wetland where they observed that local level natural resource committees should be strengthened and made fully functional in order to achieve wise use.

\subsection{Conclusion and policy implications}

The research analysed the role, relationship and consequences of institutional arrangements governing wetland access, utilization and management in three rural districts of Zimbabwe. The findings demonstrate that a multisectoral approach exists in regulation of both utilization and conservation of wetland resources. However, the degree of various institutions' participation in wetland utilization and conservation is not the same at different wetland sites, as some emphasized either more utilization, whereas others emphasized more conservation. The exceptions are the traditional leaders and wetland committees, who focus on both. Failure by all institutions to perform all functions related to wetland management threatens wetland ecology given the close link between wetland use and conservation. Local people co-operate more with institutions that promote wetland utilization for food security and sometimes give less attention to conservation issues. Thus, the study has revealed that restricting local wetland cultivation is not in the best interest of resource conservation as it may have negative effects on community livelihoods dependent on the resource.

The results further reveal that a multi-sectoral approach to wetland governance is important and unavoidable; hence the proposal for the establishment of a sound institutional structure involving local people and interested institutions. In the proposed institutional structure, roles and synergies between different institutions need to be clearly defined if sustainable wetland utilization is to be achieved. Local institutions led by traditional leaders and wetland committees should be placed at the centre of the proposed institutional framework given their current leading role in regulating both use and conservation of wetlands. The incorporation of local institutions at the centre of wetland governance system may provide a low-cost option for wetland management in resource constrained countries like Zimbabwe. The performance of government institutions was incapacitated by limited financial and human resources.

Moreover, traditional leaders and wetland committees understand local wetland use interests so that appropriate conservation strategies that embrace local livelihood needs can be adopted and implemented in unison with other institutions. Nonetheless, local authorities and government agencies should play an advisory and supervisory role to ensure that the principles of sustainable wetland utilization are complied with. In a nutshell, Zimbabwe should revisit and strengthen its institutional framework to achieve sustainable wetland utilization eliminating overlapping roles, divergent motives and different institutional dimensions. This research reinforces the need for a clear institutional structure in wetland resource management in order to promote the wise use of wetlands under the Ramsar Convention in the communal areas of Zimbabwe. Any institutional framework adopted should, however, be sensitive to local needs. Given the intrinsic link between wetland use 
and protection, it is important to place local communities at the core of any future institutional governance structure.

\section{References}

Acres B.D., Rains A.B., King R.B., Lawton R.M., Mitchell A.J.B., Rackham L.J., (1985). African dambos: Their distribution, characteristics and use. In: Thomas MF, Goudie AS (e.ds) Dambos: Small valleys in the tropics. Zeitschrift für Geomorphologie, $52: 63-86$.

Adekola O., Whanda S., Ogwu F., (2012). Assessment of policies and legislation that affect management of wetlands in Nigeria. Wetlands, 32: 665-677. http://dx.doi.org/10.1007/s13157-012-0299-3

Boast R., (1990). Dambos: A review. Progress in Physical Geography, 14(153): 10-24. http://dx.doi.org/10.1177/030913339001400201

Braun V., Clarke V., (2006). Using thematic analysis in psychology. Qualitative Research Psychology, 3(2): 77 101. http://dx.doi.org/10.1191/1478088706qp063oa

Bryman A, (2008). Social research methods. Oxford: Oxford University Press. http://dx.doi.org/10.1557/PROC1123-1123-P03-08

Chandra G., (2011). Management regimes and institutional arrangement in floodplain wetlands fisheries of Assam: An evaluation. Indian Journal of Extension Education, 47 (1\&2): 27-33.

Chidzonga M., (1994). Administrative structures and mechanisms for management of natural resources in Zimbabwe, in: Matiza T., Crafter S.A., (Eds.), Wetlands ecology and priorities for conservation in Zimbabwe. Proceedings of a seminar on wetlands ecology and priorities for conservation in Zimbabwe. IUCN., Gland, pp. 145-154.

Chuma E., Masiyandima M., Finlayson M., McCartney M., Jogo W., (2008). Guideline for sustainable wetland management and utilization: key cornerstones. http://hdl.handle.net/10568/21605. Accessed 15 October 2013

Clare S., Creed I.F., (2014). Tracking wetland loss to improve evidence-based wetland policy learning and decision making. Wetland Ecology and Management, 22: 235-245. http://dx.doi.org/10.1007/s11273-0139326-2

Dahwa E., Mudzengi C.P., Hungwe T., Shoko M.D., Poshiwa X., Kativu S., Murungweni C., (2013). Influence of grazing intensity on soil properties and shaping herbaceous plant communities in semi-arid dambo wetlands of Zimbabwe. Journal of Environmental Protection, 4: 1181-1188. http://dx.doi.org/10.4236/jep.2013.410135

Dettori J., (2010) The random allocation process: two things you need to know. Evidence Based Spine Care Journal, 1(3): 7-9. http://dx.doi.org/10.1055/s-0030-1267062

de Prada J.D., Shah F., Bravo-Ureta V., Degioanni A.J., Cisneros J.M., Cantero A., (2014). The external impact of agriculture on inland wetlands: A case study from Argentina. European Science Journal, 10(17): 99-117.

Dixon A.B., (2005). Wetland sustainability and the evolution of indigenous knowledge in Ethiopia. The Geographical Journal, 171 (4): 306 - 323. http://dx.doi.org/10.1111/j.1475-4959.2005.00172.x

Dixon A.B., Wood A.P., (2007). Local institutions for wetland management in Ethiopia: sustainability and state intervention, in: van Koppen B., Giordano M., Butterworth J., (Eds.), Community-based water law and water resource management reform in developing Countries. CABI International, Wallingford, pp. 13 - 24. http://dx.doi.org/10.1079/9781845933265.0130

Dixon A., Hailu A., Semu T., (2013). Local institutions, social capital and sustainable wetland management, in: Wood A., Dixon A., McCartney M., (Eds.). Wetland management and sustainable livelihoods in Africa. Routledge, Oxon, pp. 85-107.

Dugan P.J., (1992), Wetlands management: A critical issue for conservation in Africa, in: Matiza T., Chabwela H.N., (Eds.), Wetland conservation conference for southern Africa: Proceedings of the southern Africa development coordination conference held in Gaborone, Botswana. IUCN, Gland, pp. 21-32.

Dore D., (2001). Transforming traditional institutions for sustainable natural resource management: History, narratives and evidence from Zimbabwe's communal areas. African Studies Quarterly, 5 (3): 1-18.

FAO, (2006). Fertilizer use by crop in Zimbabwe. Rome: FAO.

FA0, SAFR, (2000). Socio-economic impact of smallholder irrigation development in Zimbabwe. Harare: FAO SAFR.

Fenken K, Mharapara I, (2002). Wetland Development and Management in SADC Countries: Proceedings of a Sub-regional Workshop. Harare: FAO and SAFR.

Gumbo D., (2006). Zimbabwe: Country Case Study on Domestic Policy Frameworks for Adaptation in the Water Sector. http://www.oecd.org/env/cc/36318866.pdf. Accessed on 15 October 2013

IWMI. (2014). Wetlands and people. Colombo: International Water Management Institute. 
Island Press, (2007). Millennium ecosystem toolkit. http://www.unpei.org/sites/default/files/PDF/ecosystems-economicanalysis/MEA-A-Toolkit.pdf. Accessed 10 February 2015

Jamu D., Rebelo L. M., Snyder K. A., (2013). Managing a Ramsar site to support agriculture and fisheries: Lake Chilwa in Malawi, in: Wood A., Dixon A., McCartney M., (Eds.), Wetland management and sustainable livelihoods in Africa. Routledge, Oxon, pp. 183 - 203.

Katerere D., (1994). Policy, institutional framework and wetlands management in Zimbabwe, in: Matiza T., Crafter S.A., (Eds.), Wetlands ecology and priorities for conservation in Zimbabwe: Proceedings of a seminar on wetlands ecology and priorities for conservation in Zimbabwe. IUCN, Gland, pp. 129-135.

Keeley J, Scoones I, (2000). Environmental policymaking in Zimbabwe: Discourses, Science and Politics. Harare, Institute of Development Studies.

Kotze D.C., (2011). The application of a framework for assessing ecological condition and sustainability of use to three wetlands in Malawi. Wetland Ecology and Management, 19: 507-520. http://dx.doi.org/10.1007/s11273-011-9232-4

Kotze D, (2010). WET-Sustainable Use: A system for assessing the sustainability of wetland use. Pretoria: Water Research Commission.

Macfarlane DM, Kotze DC, Ellery WN, Walters D, Koopman V, Goodman P, Goge C, (2007). WET-Health: A technique for rapidly assessing wetland health. Water Research Commission Report TT340/08: Pretoria.

Maclean I.M.D., Tinch R., Hassall M., Boar R., (2009) Social and economic use of wetland resources: A case study from Lake Bunyonyi, Uganda. http://www.cserge.ac.uk/sites/default/files/ecm_2003_09.pdf. Accessed on 11 November 2013

Maconachie R., Dixon A.B., Wood A., (2008). Decentralization and local institutional arrangements for wetland management in Ethiopia and Sierra Leone. Applied Geography, 29(2): 269-279. http://dx.doi.org/10.1016/j.apgeog.2008.08.003

Madebwe V., Madebwe C., (2005). An exploratory analysis of the social, economic and environmental impacts on wetlands: The Case of Shurugwi District, Midlands Province, Zimbabwe. Journal of Applied Science Research, 1(2): 228-233.

Magole L., Turner S., Buscher B., (2010). Towards an effective commons governance system in Southern Africa? International Journal of Commons 4(2): 602-620. http://dx.doi.org/10.18352/ijc.255

Mahonge C. P. I. (2010) Co-managing social-ecological systems in Tanzania: The case of Lake Jipe wetland. Wagenigen Academic Publishers, Netherlands.

Marambanyika T., Mutsiwegota C., Muringaniza K.C.R., (2012). Importance of community participation in sustainable utilization of wetlands: Case of Chebvute in Zvishavane District of Zimbabwe. Journal of Environmental Science and Engineering B, 1(7): 832-844.

Marambanyika, T., Beckedahl, H. R., Ngetar, N. S., Dube, T., (2016) Assessing the environmental sustainability of cultivation systems in wetlands using the WET-health framework in Zimbabwe. Physical Geography. http://dx.doi.org/10.1080/02723646.2016.1251751

Marambanyika, T., Beckedahl, H., (2016) The missing link between awareness and the implementation of wetland policy and legislation in communal areas of Zimbabwe, Wetlands Ecology and Management, 24 (5) 545 -563. DOI 10.1007/s11273-016-9486-y

Matiza T., (1994). Wetlands in Zimbabwe: An overview, in: Matiza T., Crafter S.A., (Eds.), Wetland ecology and priorities for conservation in Zimbabwe: Proceedings of a Seminar on Wetlands of Zimbabwe. IUCN, Gland, pp. 3-10.

Matsa M., Muringaniza K., (2011). An assessment of the land use and land cover changes in Shurugwi district, Midlands province, Zimbabwe. Ethiopian Journal of Environmental Studies and Management, 4 (2): 88-101. http://dx.doi.org/10.4314/ejesm.v4i2.10

Mbereko A, (2008). Understanding socio-economic outcomes of technological innovations over access, use and management of natural resources in Zimbabwe: A case study of Zungwi Vlei (Zvishavane District). MSc Thesis. University of Zimbabwe, Center of Applied Social Sciences.

McCartney MP, Masiyandima M, Houghton-Carr HA, (2005). Working wetlands: Classifying wetland potential for agriculture, Research Report 90. Colombo: International Water Management Institute.

Mharapara IM, Munena MD, Mkwanda R (1998) Zimbabwe country paper: Experiences on wetland characterisation, classification, management and utilization for sustainable agricultural development: A case of wetland research. In: FAO (Ed), Wetland characterisation and classification for sustainable agricultural development. FAO/SAFR, Harare

Millennium Ecosystem Assessment, (2005). Ecosystems and human well-being: Synthesis. Washington: Island Press.

Mitsch WJ, Gosselink JG, (1993). Wetlands. New York: Van Nostrand Reinhold.

Morris K, Reich P, (2013). Understanding the relationship between livestock grazing and wetland condition. Arthur Rylah Institute for Environmental Research Technical Report Series No. 252. Heidelberg: Department of Environment and Primary Industry. 
Morzaria-Luna H.N., Castillo-Lopez A., Danemann G.D., Turk-Boyer P. (2014). Conservation strategies for coastal wetlands in the Gulf of California, Mexico. Wetland Ecology and Management, 22: $267-288$. http://dx.doi.org/10.1007/s11273-013-9328-0

Moses 0, (2008). An institutional analysis of the management of wetland resources: A comparative study of Flóahreppur municipality in South Iceland and Oyam district in Uganda. Land restoration training programme. Agricultural University of Iceland.

Mugandani R., Wuta M., Makarau A., Chipindu B., (2012) Re-classification of agro-ecological regions of Zimbabwe in conformity with climate variability and change. African Crop Science Journal, (20)2: 361 369.

Mujaju C., Mtetwa G., Muchingami Z., Mugabe F.T., Munodawafa A. (2013). The effect of using inorganic and cattle manure with different top-dressing rates of ammonium nitrate on yield of maize under wetland conditions. World Journal of Agricultural Sciences, 1(1): 018-025.

Murombedzi J.C., (1994). Wetlands conservation under common property management regimes in Zimbabwe, in: Matiza T., Crafter S.A. (Eds.), Wetlands ecology and priorities for conservation in Zimbabwe: Proceedings of a seminar on wetlands ecology and priorities for conservation in Zimbabwe. IUCN, Gland, pp. 113-121.

Musamba E.B., Ngaga Y.M., Boon E.K., Giliba R.A., (2011). Impact of socio economic activities around Lake Victoria: Land use and land use changes in Musoma Municipality, Tanzania. Journal of Human Ecology, 35(3): 143-154.

Mutepfa F., Marongwe N., Matondi P., (2010). Land, in: Feresu S.B., (Ed.), Zimbabwe environment outlook: our environment, everybody's responsibility. Harare: The Ministry of Environment and Natural resources management.

Mutyavaviri F, (2006). Impact of cultivation on soil and species composition of the Monavale Vlei, Harare. Msc Thesis. University of Zimbabwe, Department of Biological Sciences.

Msipa M, (2009). Land use changes between 1972 and 2008 and current water quality of wetlands in Harare, Zimbabwe. MSc Thesis. University of Zimbabwe, Department of Biological Sciences.

Mwakubo S.M., Obare G.A., (2009). Vulnerability, livelihood assets and institutional dynamics in the management of wetlands in Lake Victoria watershed basin. Wetland Ecology and Management, 17: 613626. http://dx.doi.org/10.1007/s11273-009-9138-6

Ngorima GT, (2006). Towards sustainable use of Marula (Sclerocarya birrea) in the Savannah woodlands of Zvishavane District, Zimbabwe. MSc Thesis. University of the Witwatersrand.

Nyariki DM, (2009). Household Data Collection for Socio Economic Research in Agriculture: Approaches and Challenges in Developing Countries. Nairobi: University of Nairobi.

Pollard S, Kotze D, Ellery W, Cousins T, Monareng J, King K, Jewitt G, (2005), Linking water and livelihoods: The development of an integrated wetland rehabilitation plan in the communal areas of the Sand River Catchment as a test case. South Africa: Association for Water and Rural Development.

Ramsar Convention Secretariat, (2010). Wise use of wetlands: Concepts and approaches for the wise use of wetlands. Gland: Ramsar Convention Secretariat.

Russi D, ten Brink P, Farmer A, Badura T, Coates D, Förster J, Kumar R, Davidson N, (2013). The economics of ecosystems and biodiversity for water and wetlands. London: IEEP.

Shine C, de Klemm C, (1999) Wetlands, Water and the Law. Using law to advance wetland conservation and wise use. Gland: IUCN.

Sibanda T, (2005). Assessing the impact of livestock trampling on soil compaction on Intunjambili wetland, Matopo. BSc Dissertation, University of Zimbabwe.

Silima V, (2007). A review of stakeholder interests and participation in the sustainable use of communal wetlands: The case of the Lake Fundudzi catchment in Limpopo Province, South Africa. Dissertation, Rhodes University.

Turner R.K., van den Bergh J.C.J.M., Soderqvist T., Barendregt A., van der Straaten J., Maltby E., van Ierland E.C. (2000). Ecological-economic analysis of wetlands: Scientific integration for management and policy. Ecological Economics, 35: 7-23. http://dx.doi.org/10.1016/S0921-8009(00)00164-6

Vincent V, Thomas RG, (1960). An agro-ecological survey of Southern Rhodesia Part 1: Agro-ecological Survey. Salisbury: Government Printers.

Were A. N., Isabirye M., Poesen J., Manertens M., Deckers J., Mathijs E. (2013) Decentralised governance of wetland resources in the Lake Victoria Basin of Uganda. Natural Resources, 4: 55 - 64.

Whitlow R, (1989). A review of dambo gullying in south-central Africa. Zambezia, XVI(ii): 123-150.

Zimstat, (2012). Census 2012 preliminary report. Harare: Zimstat.

Zsuffa I., van Dam A.A., Kaggwa R.C., Namaalwa S., Mahieu M., Cools J., Johnston R. (2014). Towards decision support-based integrated management planning of papyrus wetlands: A case study from Uganda. Wetland Ecology and Management, 22:199-213. http://dx.doi.org/10.1007/s11273-013-9329-z 